MILAN AMBROŽ, Ph.D.

E-mail: ambrozmilan@siol.net

BRANKO LOTRIČ, M.Sc.

E-mail: brane.lotric@bb-kranj.si

$\mathrm{B} \& \mathrm{~B}$ education and training

Ljubljanska cesta 30, SI-4000, Kranj, Republic of Slovenia
Transport Logistics

Preliminary Communication

Accepted: Feb. 12, 2009

Approved: Sep. 16, 2009

\title{
IMPACT OF A MEDIATING ROLE OF REPURCHASE INTENTIONS ON CUSTOMER RETENTION
}

\begin{abstract}
Research in the area of packaged tour services, provided by the national and foreign tour operators has concentrated on mutual relationships among tourist-perceived service quality, satisfaction and repurchase intentions. However, little research in this domain has been done to explain the impact of repurchase intentions of experienced tourists on the relation between perceived quality of service and their satisfaction. This model was tested using substantial data set of experienced tourists with time span of three years. While previous literature has suggested that quality perceptions impose direct effect on tourist satisfaction, this study shows that such effect is more powerful when mediated by repurchase intentions of experienced tourists. The quality of packaged tour services mediated by repurchase intentions of the experienced tourist is expected to be paramount for the retention of the tourist in the long term.
\end{abstract}

\section{KEY WORDS}

repurchase intentions, quality, packaged service, services chain, tour operator, retention, tourist satisfaction.

\section{INTRODUCTION}

Customer satisfaction has become a crucial measure of competitiveness in tourist markets throughout the world, and the service quality has become the primary determinant for creating overall customer satisfaction [1]. Intense competition puts more and more focus on customer satisfaction that primarily results from the high quality of service. The necessity to achieve service excellence is closely related to the lower margins and tighter budgets of the customers. The answer to this challenge could be found in powerful integrated and packaged tour services, especially in the field of leisure and tourism. This is the reason why for every tour operator, tourism and hospitality firm, transport company and local tourism organization the use of proper technology to gather information on the market demands and exchange it between the organizations that participate as a service provider in packaged tour service is of the highest importance [2], [3].
Researchers and managers thrive for new information about service quality for reasons that are closely related to customer satisfaction and their repurchase intentions. In this context the building of the packaged tour service chain gains specific attention as it helps in learning the factors that will provide a direction for improvements.

There are many academic studies that address service quality and customer satisfaction [4], [5]. Examination of mutual relationships among tourist-perceived service quality, value, satisfaction, and intentions to repurchase packaged tour services from tour operators received substantial attention [6]. The research shows that quality perceptions impose a direct effect on tourists' repurchase intentions when such effect is fully mediated by tourists' satisfaction. On the other hand, the relationship between service quality in the integrated packaged tour services and tourist satisfaction mediated by the intentions to repurchase packaged tour services is mainly neglected although it is cheaper and less time consuming to retain a tourist than gain a new one. This relationship is the aim of this study that examines how the perception of the quality of service of a packaged tour influences the satisfaction of the experienced tourist with repurchase intentions.

It has been well proven that quality of service, customer satisfaction, and customer repurchase intentions are strongly linked. At the same time, there is lack of knowledge about how experienced tourist perceives the quality of chain of services within the packaged tour service and which services add most and least to their satisfaction and need more attention from the tour operator. This paper proposes a customer-centred model of mutual relationships among tourist-perceived service quality, tourists' satisfaction, and intentions to repurchase packaged tour services. The customer centricity is defined as the importance that service providers place on their customers' needs and expectations relating to a company service provision [7]. It shows that quality perceptions impose direct effect on tourists' satisfaction when such effect is 
fully mediated by the tourist repurchase intentions. Its aim is also based on two important facts that every tour operator needs to know: (1) the quality of their service, resulting in customer satisfaction rating mediated by the repurchase intentions, and (2) the variability of the customer satisfaction with the services included in the packaged tour services.

\subsection{Packaged tour services chain management}

Due to its role as the driver of external and internal integration of packaged tour services [8], supply chain management may be uniquely critical to creating a market-oriented organization. In the last decade several concepts of supply chain management emerged in packaged tour services. As a key integrator with customers, suppliers, and third party service providers, supply chain management is positioned to generate service market intelligence by interacting with each of these parties [9]. With an effective fresh look at the service flow a customer-focused integrated system of leisure and tourism services could be built. The packaged tour services, is a very good example of a service integrated system, because it is very important for the satisfaction with the services how they are qualified and ranked, and how they are perceived by tourists [10].

From a tourist point of view, tourism services are always a product of a whole package of individual services. These services are: the journey to the destination, stay at a vacation hotel, excursions to the surroundings, shopping and recreation activities and finally the trip home, all of them linked in a chain. The same process can be observed at a level of the individual hotel. In every hotel service package, a tourist plays several roles and gains different experiences from every service that are closely intertwined: information about the hotel, arrival to the hotel, moving into the room, eating in the restaurant, using recreation facilities and check-out. Each service in the package adds unique value to the common view of the services and to the positive or negative experiences of the tourist.

To study the perception of tourists about the quality of packaged tour services, the services should be split in service components which constitute several heterogeneous dimensions of the corresponding services package. Within each service component, there are a number of service features that are subjected to customer rating to become the foundation for the packaged tour service strategy. For example, when the flight transportation service component of a packaged tour is considered, information, assistance, flight ticket, baggage and seat arrangements are the relevant features. Instead of ad-hoc solutions for each provider in the packaged tour services, a customer-oriented model based on the supply chain management is needed to instantly monitor the quality of services and customer satisfaction. As a result of effective information exchange about the quality of the services in the packaged tour and about the tourist satisfaction, more value is delivered to the tourist [11].

\subsection{Quality of services in packaged tours}

Research in the area of services has concentrated on service quality [12], [13], [14], [15], [16] and overall customer satisfaction [17], [14], [18], [19]. One of the best-known theoretical approaches has been developed by the work of Parasuraman and associates [20], who developed the 'four gap model'. The model predicts four gaps of expected service and the perceived quality of the service received. The higher the gap between the expected and the perceived quality, the lower is the quality. Some researchers proposed that service quality is one of the antecedents of consumer satisfaction [14]. However, they found that service quality had less of an effect on purchase intentions than did the consumer satisfaction.

Service quality depends upon customer expectations before the service is delivered, during the service delivery system and after the completion of the service, and is defined as the discrepancy between consumer expectations and management perceptions of those expectations that are specified and executed [20]. Further, in the packaged tour services, we are dealing with a system of impacts within the interdependent services. Further, there is a necessity to determine the quality of service as a system of impacts with interdependent elements that is open to entry of new ones. The most important is that interdependent elements or services in the tour packaged services satisfy the tourist needs and strengthen their intentions to repurchase the services by the same tour operator [21]. At the same time, critical information about the quality of services during the tour strengthens the competitive edge of the tour operator and helps building its winning customer-oriented strategy [14], [22].

When different service providers enter the supply service chain of the tour packaged services, some important facts about quality should be considered. Firstly, different service providers and different customers share different views about the quality of the packaged services. Secondly, customers, employees and management may have different values and different cultural and social backgrounds for quality assessment, which influence their perceptions of service quality [23]. Furthermore, the concept of service is closely related to customer point of view, since it was their perception of the outcome that constituted that service [24]. Thirdly, experienced packaged tour customers share different views of tour services. Results 
of the study done by [25] show how repeat and first-time visitors develop their satisfaction and return intention judgments. Both the first-time and repeat visitors commonly regard quality of food, quality of accommodation, hospitality and safety as reason for coming back. At the same time, repeat experienced visitors consider different additional services to develop their repurchase intentions and show more willingness to repeat the service. Customers seek a set of needs and wishes, partly related to the essential service and partly to subsidiary services [26], [27]. For example, the main purpose might be a hotel stay and subsidiary services may be scenic visits, recreation and attending local events. Customers have some preliminary expectations and want to fulfil them, especially those with broader packaged tour experience. When actually presented with these services, they will form impressions and compare them to expectations. Their level of satisfaction will be determined by the perceived quality of service.

\subsection{Quality of service and customer satisfaction}

More satisfied customers tend to be loyal and are more inclined to producing several benefits to organization [28], [29]. Repeat service always generates income and costs are lower in comparison to the process of acquiring new customers. More satisfied customers always spread good news about the services of a tour operator and recommend them to the new customers [29]. Several studies related quality of service with customer satisfaction and their repurchase intentions. Satisfaction is considered, namely, as a function of perceived quality and "disconfirmation" - the extent to which perceived quality fails to match pre-purchase expectations [30]. On the other hand, customer satisfaction can be connected with loyalty of the customer and with customer value, and becomes a function of customer expectations and perceived quality [31]. Furthermore, satisfaction increases customer loyalty and decreases switching behaviour that is characterized by switching barriers like search, learning and emotional cost and risks [31]. The quality of service can be seen differently as an effect on behavioural intentions, which are mediated by customer satisfaction [32]. Some researchers argue that service quality and customer satisfaction affect retention simultaneously [33]. The actual purchase is based on purchase intentions and is defined as tour experience [34], [35]. Purchase intentions involve individual assessment of the subjective probability or degree of an effort one will exert to purchase in the future [36].

Building upon these findings it is concluded that the quality of service is the indicator of customer satisfaction mediated by repurchase intentions of experi-

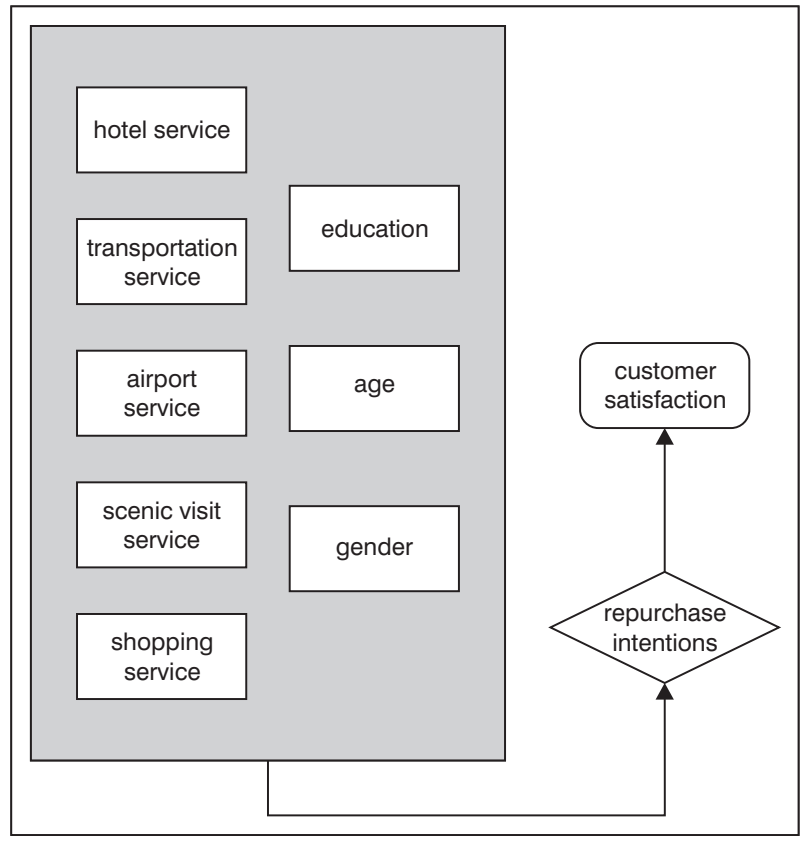

Figure 1 - Repurchase intentions model

enced tourists. As the result the next two research hypotheses are:

H1: The quality of service of the packaged tour services is directly and positively related to customer satisfaction;

$\mathrm{H} 2$ : The quality of service mediated by repurchase intentions of experienced customers of packaged tour services is indirectly and positively related to customer satisfaction.

\section{RESEARCH RESULTS AND SURVEYS OF METHODS}

According to the purpose of this study, the overall process of developing an instrument for the study of the mediating role of the repurchase intentions was divided into three separate parts. Part one generated a sample of items, by literature research, focus groups comprised of tourism students, and 22 Slovenian and 4 foreign tour operators.

In part two, data were collected from the student and tour operator focus groups, measures purified, and the initial scale of instrument developed. The sessions with the focus groups of students of tourism and with representatives of tour operators were mind-mapped and used to generate a scale of items. In part three, data were collected from a diverse sample of 460 experienced tour packaged tour customers who usually bought packaged tour services from the tour operator in the respective study. Using a sample of 461 respondents, data were examined using principal component analysis as the extraction method and varimax as a technique of rotation. The importance measure in 
the study was done through the application of multiple regression analysis. To test the mediating role of repurchase intentions where repurchase intentions are hypothesized as a key mediator of relationships between perceived service quality and customer satisfaction a regression model was developed.

A comprehensive survey was distributed through Slovenian (80\%) and foreign tour operators $(20 \%)$ to the 510 experienced tourists that purchased packaged tour services for various tourist destinations all over the world in the last year. The respondents participated voluntarily and they were assured that their individual responses would be treated as confidential. The questionnaire comprised thirty-one items: twenty-four items for service quality and seven items for customer satisfaction. The response rate was $90 \%$. Two hundred and ten of them were men and two hundred and fifty were women. The average age of the respondents in the study was 35 years. Table 1 shows the respondents profile.

Table 1 - Sample data

\begin{tabular}{||c|c|l|r|r||}
\hline \hline & variable & \multicolumn{1}{|c|}{ features } & & \\
\hline \hline \multirow{2}{*}{1} & \multirow{2}{*}{ gender } & men & 210 & \\
& & women & 251 & \\
\hline \multirow{2}{*}{3} & \multirow{2}{*}{ educe } & average in years & 35 & \\
& & range in years & $15-80$ & \\
& & elementary school & 60 & $13 \%$ \\
& & high school & 241 & $54 \%$ \\
& & bachelor/university degree & 127 & $27 \%$ \\
& & master degree & 21 & $5 \%$ \\
& & & 4 & $1 \%$ \\
\hline
\end{tabular}

From the research model of Figure 1, the factor analysis induced one set of factors as follows:

- Hotel service quality: there were seven indicators in this study that included: (1) location attractiveness, (2) commodity of the hotel facilities, (3) commodity of the hotel rooms, (4) food variety, (5) additional services, (6) recreation equipment, (7) professional recreation management;

- Airport service quality: there were six indicators in this study that included: (1) comprehensive flight information, (2) custom declaration assistance, (3) flight ticket assistance, (4) baggage preparation assistance (5) speedy and safe baggage check and transport, (6) seat arrangement during the flight;

- Scenic visit quality: there were two indicators in this study that included: (1) historical and cultural destination features, (2) comprehensive cultural and historical information and presentation of the destination; Transportation service quality: There were three indicators in this study that included: (1) food during the flight, (2) positive attitude and professional conduct of flight personnel, (3) flight commodity;
- Customer satisfaction: there were six indicators in the study that included: (1) new social contacts, (2) original tour experiences, (3) relaxation and new energy, (4) fulfilled expectations, (5) active participation in all events, (6) open and spontaneous event management;

- Shopping service quality: security of events (1), variety of shopping opportunities, (2) original products to buy, (3) security of the shopping area, (4) original products (5) professional help from a tour guide;

- Control variables: age, education and gender.

Mediating variable: "Repurchase intentions" is stated as: "I am determined to travel with the same tour operator in the future" (yes/no). Respondents assessed all items on a five-point Likert-type scale ranging from (1) »strongly disagree « to (5) »strongly agree «. Single item questions were used to ascertain the respondent gender, age and education. Repurchase intentions were measured on a categorical scale with yes or no. A total of 461 respondents completed and returned the questionnaires. Gender of respondents was coded (1) for men and (2) for women. Age of respondents was coded by open question. Education consisted of five levels: (1) elementary school (2) high school, (3) bachelor/university degree, (4) master degree, (5) doctorate.

\section{DISCUSSION}

Using a sample of 460 respondents, the data were examined using the principal component analysis as the extraction method and varimax as a technique of rotation on two sets of variables. The first set of variables consisted of items about the airport and flight service, hotel service, event service, scenic visit service and tour guide service. Specifying five factors were found to have produced the most interpretable results. These factors were interpreted as airport service quality, quality of transportation, hotel service quality, scenic visit service quality and tour guide service quality, and explained $56 \%$ of variance. The larger amount of variance $(31.33 \%)$ is accounted for by the factor »Hotel service quality «, followed by the factor »Airport service quality « that accounted for $(6.66 \%)$ of variance. Factor »Scenic visit service quality« accounted for $(5.52 \%)$ of variance. Factor $»$ Transportation service quality « accounted for $(4.95 \%)$ of variance. Factor »Customer satisfaction « accounted for $(4.29 \%)$ of variance, and the least variance was accounted for by the factor »Shopping and events experience quality « - $3.60 \%)$ of variance.

Table 2 depicts the loading of 29 items on each factor. The loadings below. 40 were dropped from the analysis. Moreover, the overall Cronbach's alfa results 
Table 2 - Principal components factor analysis with varimax normalized rotation

\begin{tabular}{|c|c|c|c|c|c|c|c|c|c|}
\hline $\mathrm{F}$ & Hotel & Airport & Scenic visit & Transport & $\begin{array}{l}\text { Satisfac- } \\
\text { tion }\end{array}$ & Shopping & Average & StD & $\begin{array}{c}\text { Cronbach's } \\
\text { alfa }\end{array}$ \\
\hline 1 & 0.63 & & & & & & 3.76 & 1.06 & \\
\hline 2 & 0.79 & & & & & & 3.59 & 1.04 & \\
\hline 3 & 0.74 & & & & & & 3.70 & 0.96 & \\
\hline 4 & 0,61 & & & & & & 3.68 & 1.12 & \\
\hline 5 & 0.67 & & & & & & 3.19 & 1.13 & .83 \\
\hline 6 & 0.57 & & & & & & 3.40 & 1.01 & \\
\hline 7 & 0.55 & & & & & & 3.40 & 1.10 & \\
\hline 8 & & 0.47 & & & & & 3.68 & 0.91 & \\
\hline 9 & & 0.77 & & & & & 3.49 & 1.06 & \\
\hline 10 & & 0.69 & & & & & 3.82 & 1.03 & .72 \\
\hline 11 & & 0.73 & & & & & 3.25 & 1.09 & \\
\hline 12 & & 0.45 & & & & & 3.56 & 1.19 & \\
\hline 13 & & & 0.77 & & & & 4.04 & 0.95 & \\
\hline 14 & & & 0.80 & & & & 3.82 & 0.97 & .58 \\
\hline 15 & & & & 0.77 & & & 3.23 & 1.04 & \\
\hline 16 & & & & 0.49 & & & 3.96 & 0.88 & .62 \\
\hline 17 & & & & 0.72 & & & 3.52 & 1.05 & \\
\hline 18 & & & & & 0.65 & & 3.74 & 1.08 & \\
\hline 19 & & & & & 0.60 & & 3.90 & 0.88 & \\
\hline 20 & & & & & 0.72 & & 4.10 & 0.94 & \\
\hline 21 & & & & & 0.49 & & 3.97 & 0.96 & .85 \\
\hline 22 & & & & & 0.67 & & 3.83 & 1.01 & \\
\hline 23 & & & & & 0.69 & & 3.45 & 1.08 & \\
\hline 24 & & & & & 0.41 & & 3.60 & 1.02 & \\
\hline 25 & & & & & & 0.65 & 3.45 & 1.07 & \\
\hline 26 & & & & & & 0.64 & 3.53 & 0.97 & \\
\hline 27 & & & & & & 0.75 & 3.38 & 0.95 & .76 \\
\hline 28 & & & & & & 0.56 & 3.66 & 1.04 & \\
\hline 29 & & & & & & 0.49 & 3.32 & 1.13 & \\
\hline
\end{tabular}

show that the instrument is highly reliable (. 92). Cronbach's alfa test of reliability of factors in the factor analysis shows that they are highly reliable: hotel service quality $=.83$; airport service quality $=.72$; scenic service quality $=.58 ;$ transportation quality $=$. 62 ; customer satisfaction quality $=.85$; shopping and event experience quality $=.76$.

Table 3 presents the Pearson's correlations for all the variables examined. Some significant correlations are also shown between control variables gender and scenic visit service and shopping, education and age and accommodation service. Customer satisfaction correlates positively and significantly with all pack- aged tour services. It correlates negatively with repurchase intentions. Correlations between repurchase intentions and packaged tour services are significant and negative, revealing the exclusion role of repurchased intentions. Negative repurchase intentions are the result of poor service quality and the result of low customer satisfaction.

The first objective of this study was to examine extent to which packaged tours services quality can predict customer satisfaction, in an attempt to provide insight into repurchased intentions. According to a Table 4 five of five packaged tour services and one control variable are important customer satisfaction pre- 
Table 3 - Correlation analysis of variables in the study

\begin{tabular}{|l|c|c|c|c|c|c|c|c|c|c||}
\hline \hline \multicolumn{1}{|c|}{$\mathrm{N}=446$} & 1 & 2 & 3 & 4 & 5 & 6 & 7 & 8 & 9 & 10 \\
\hline \hline gender & $\mathbf{1 . 0 0}$ & & & & & & & & & \\
\hline age & 0.02 & $\mathbf{1 . 0 0}$ & & & & & & & & \\
\hline education & 0.01 & $0.34^{*}$ & $\mathbf{1 . 0 0}$ & & & & & & & \\
\hline repurchase intentions & 0.07 & -0.08 & -0.03 & $\mathbf{1 . 0 0}$ & & & & & & \\
\hline accommodation service & -0.09 & $0.16^{*}$ & 0.05 & $-0.36^{*}$ & $\mathbf{1 . 0 0}$ & & & & & \\
\hline airport service & -0.01 & 0.05 & -0.03 & $-0.22^{*}$ & $0.40^{*}$ & $\mathbf{1 . 0 0}$ & & & & \\
\hline scenic visit service & $-0.15^{*}$ & 0.06 & -0.02 & $-0.30^{*}$ & $0.38^{*}$ & $0.25^{*}$ & $\mathbf{1 . 0 0}$ & & & \\
\hline transportation & -0.08 & 0.05 & -0.02 & $-0.29^{*}$ & $0.37^{*}$ & $0.42^{*}$ & $0.26^{*}$ & $\mathbf{1 . 0 0}$ & & \\
\hline customer satisfaction & -0.08 & 0.02 & -0.04 & $-0.46^{*}$ & $0.64^{*}$ & $0.45^{*}$ & $0.46^{*}$ & $0.39^{*}$ & $\mathbf{1 . 0 0}$ & \\
\hline shopping & $-0.10^{*}$ & 0.09 & 0.02 & $-0.29^{*}$ & $0.56^{*}$ & $0.48^{*}$ & $0.47^{*}$ & $0.34^{*}$ & $0.62^{*}$ & $\mathbf{1 . 0 0}$ \\
\hline
\end{tabular}

*Marked correlations are significant at $\mathrm{p}<.05000$

dictors in service settings $\left(\mathrm{R}^{2}=0.55, \mathrm{~F}=70.29\right.$, $\left.\mathrm{p}<0.0000^{* * *}\right)$. Apparently, hotel service, airport service, scenic visit service, transportation service, shopping service significantly and directly impact customer satisfaction. Such a finding implies that being competitive as a tour operator, means to deliver quality packaged service to customers along the whole service chain.

Table 4 - Regression analysis

\begin{tabular}{|l|c|c||}
\hline \hline & $\begin{array}{c}\text { direct } \\
\text { realtionship }\end{array}$ & $\begin{array}{c}\text { mediated } \\
\text { relationship }\end{array}$ \\
\hline \hline hotel service & $0.38^{* * *}$ & $0.33^{* * *}$ \\
\hline airport service & $0.10^{*}$ & $0.10^{*}$ \\
\hline scenic visit service & $0.14^{*}$ & $0.11^{*}$ \\
\hline transportation service & $0.08^{*}$ & 0.05 \\
\hline shopping service & $0.27^{* * *}$ & $0.26^{* * *}$ \\
\hline repurchase intentions & & $0.19^{*}$ \\
\hline gender & 0.01 & 0.01 \\
\hline age & -0.07 & $-0.07^{*}$ \\
\hline education & -0.93 & -0.03 \\
\hline adjusted R2 & 0.55 & 0.58 \\
\hline F-ratio & 70.29 & 69.09 \\
\hline
\end{tabular}

Notes: *p , 0.05; **p , 0.01; ***p, 0.001; entries are significant standardized regression coefficients

Given the customer focus of our study, we opted to use customers' satisfaction as the outcome variable. When tourists gain positive experience repurchasing by the same tour operator, the link between their perceptions of the packaged services quality and their satisfaction with it is strengthened. Repeating multiple regression by including repurchase intentions as a mediating effect into the equation, revealed some differences from the previous model. According to Table 4 four of five packaged tour services and one control variable are important customer satisfaction predictors in service settings. $\left(\mathrm{R}^{2}=0.58, \mathrm{~F}=69.09\right.$, $\left.\mathrm{p}<0.0000^{* * *}\right)$. Hotel service, airport service, scenic visit service, shopping service and age of the tourists, significantly impact customer satisfaction when mediated by repurchase intentions of the tourists. Transportation service dropped out of the equation. Possible explanation could be found in the accelerated stress associated with the travel by air. Furthermore, age also significantly influences customer satisfaction.

\subsection{Limitations and direction for future research}

This study, like the others, has some limitations that need to be considered when interpreting the results. First of all, tourists assessed their experiences with the tour operator. We cannot be certain that their intentions are based on their repurchased experiences with the same operator, even though we asked them to take their tour experiences in the last year in the consideration. In the present study, the experiences of tourists were not explicitly measured and described. That would be of the utmost significance in the future studies. Besides, the respondents rated the quality of the packaged tour services after some time when the tour ended. It would be more efficient to measure the quality of the particular service in the service chain immediately after the service is completed and compare it to the expectations of the tourists with the same service. Despite these limitations, it is strongly believed that results of this study provide a base for understanding the mediating role of the repurchased intentions of the experienced tourist on the relationship between the quality of services in the packaged tour services and their satisfaction. 


\section{CONCLUSION}

Severe competition requires adjustments in the packaged tour services that are related to the quality of each service in the package and to the efforts to retain tourists. Repurchase intentions do mediate the relationship between the quality of the packaged services and customer satisfaction, especially when older tourists are at stake. In this context, this study intended to unveil the effect that repurchase intentions of experienced tourists have on customer satisfaction. The findings suggest that when trying to predict the impact of the packaged tour services on customer satisfaction, repurchase intentions can be very important.

In this study, the relationship between quality of services in the packaged tour services and tourists' satisfaction with it was examined. Results show that quality of particular services in the package, directly predict satisfaction of the tourists. Further, our aim was to research the role of the experiences tourists repurchase intentions in this relationship, so we hypothesized that the mediating role of repurchase intentions will be positive and will strengthen the satisfaction of the tourists' with the packaged tour services. As was expected, packaged tour services quality experience with the same tour operator has positive influences on tourist satisfaction. This result is consistent with the notion that satisfaction increases customer loyalty and decreases their switching behaviour [31]. Furthermore, the packaged tour services experience was found to obtain favourable knowledge about the quality of the chain of services and thus successful repurchase of the package tour by the same tour operator. This result also implies that to increase the customer desired level of perceived satisfaction requires balanced packaged services quality and coordination of services in a chain of services. It was also argued that the positive tourist repurchase experiences with regard to the quality of packaged tour services induced their satisfaction.

\section{Dr. MILAN AMBROŽ}

E-mail: ambrozmilan@siol.net

Mag. BRANKO LOTRIČ

E-mail: brane.lotric@bb-kranj.si

$\mathrm{B} \& \mathrm{~B}$ education and training

Ljubljanska cesta 30, SI-4000, Kranj, Republika Slovenija

\section{POVZETEK}

\section{VPLIV PONOVNEGA NAKUPA PAKETIRANE POTOVALNE STORITVE NA DOLGOROČNI ODNOS S TURISTOM}

Raziskave na področju paketiranih potovalnih storitev, ki jih ponujajo nacionalni in tuji posredniki potovanj, se osredinjajo zlasti na kakovost storitev in na zadovoljstvo kupca in na njun vpliv na ponovni nakup storitev. Zelo malo raziskav obravnava posredniško vlogo želja turista po ponovnem nakupu paketirane potovalne storitve pri istem ponudniku storitev $v$ prihodnosti. Mediacijsko vlogo želja po ponovnem nakupu storitve med kakovostjo storitev in zadovoljstvom turista s paketiraNo. potovalNo. storitvijo, smo preskusili s podatki, ki smo jih tri leta zbirali pri nacionalnih in pri tujih ponudnikih storitev. Rezultati naše raziskave kažejo da pretekle pozitivne izkušnje turistov s paketiraNo. potovalNo. storitvijo pri istem ponudniku storitev, krepijo njihov dolgoročni odnos s ponudnikom storitve.

\section{KLJUČNE BESEDE}

želje po ponovnem nakupu storitve, kakovost, paketirana storitev, veriga storitev, posrednik storitev, dolgoročni odnos, zadovoljstvo turista

\section{LITERATURE}

[1] Harding, F. E.: Logistics service provider quality: private measurement, evaluation and improvement, Journal of Business Logistics, Vol. 19 No. 1, 1998, pp. 103-20

[2] Lewis R. C., Pizam, A.: Guest Surveys: A Missed Opportunity, Cornell Hotel and Restaurant Administration Quarterly, Vol. 22, No. 3, 1981, pp. 37-44

[3] Nitin, S., Desmukh, S. G., Prem, V.: Service quality models: a review, International Journal of Quality \& Reliability Management, Vol. 22, No. 9, 2005, pp. 913-949

[4] Gilbert, G. R., Veloutsou, C., Goode, M. M. H., Moutinho, L.: Measuring customer satisfaction in the fast food industry: A cross-national approach, The Journal of Services Marketing 18, No. 5, 2004, pp. 371-383

[5] Qin, H., Prybutok, V. R.: Service Quality, Customer Satisfaction, and Behavioral Intentions in Fast-Food Restaurants, International Journal of Quality and Service Sciences, 2008, manuscript was accepted for publication.

[6] Yanqun, H., Haiyan, S.: A Mediation Model of Tourists' Repurchase Intentions for Packaged Tour Services, Journal of Travel Research, Vol. 47, No. 3, 2009, pp. 317$-331$

[7] Kelly, S. W.: Developing Customer Orientation among Service Employees, Journal of the Academy of Marketing Science 20 (1): 1992, pp. 27-36

[8] Flint, D. J., Larsson, E., Gammelgaard, B., Mentzer, J.: Logistics innovation: a customer value-oriented social process, Journal of Business Logistics, Vol. 26, No. 1, 2005, pp. 113-47

[9] Flint, D. J., Mentzer, J. T.: Logisticians as Marketers: their Role when Customers' Desired Value Changes, Journal of Business Logistics, Vol. 21, No. 2, 2000, pp. $19-45$

[10] Dotchin, J. A., Oakland, J. S.: Total quality Management in services, International Journal of Quality and Reliability Management”, Vol. 11, No. 3, 1994, pp. 27-42

[11] Halldorsson, A., Kotzab, H., Mikkola, J. H., Skjoett-Larsen, T.: Complementary theories to supply chain management, Supply Chain Management: An International Journal, Vol. 12, No. 4, 2007, pp. 284-296 
[12] Berry, Zeithaml and Parasuraman: Five Imperatives for Improving Service Quality, Sloan Management Review, Summer 1990, pp. 29-38

[13] Bitner, M. J.: Evaluating Service Encounters: The Effects of Physical Surroundings and Employee Responses, Journal of Marketing, Vol. 54, No. 2, 1990, pp. 69-82

[14] Cronin J. Joseph Jr., Taylor, S. A.: Measuring Service Quality: A Reexamination and Extension. Journal of Marketing, Vol. 56, No. 3, 1992, pp. 55-68

[15] Boulding, W., Kalra, A., Staelin, R., Zeithaml Valarie V. A.: A dynamic process model of service quality: From expectations to behavioral intentions, Journal of Marketing Research, Vol. 30, No. 1, 1993, pp. 7-27

[16] Skalpe O., Sandvik, K.: The economics of quality in the hotel business. Tourism Economics, Vol. 8, No. 4, 2002, pp. 361-376

[17] Singh, J.: Voice, Exit, and Negative word-of-mouth Behaviors: An Investigation Across Three Service Categories, Journal of the Academy of Marketing Science, Vol. 18, No. 1, 1990, pp. 1-15

[18] Anderson E. W., Sullivan, M. W.: The Antecedents and Consequences of Customer Satisfaction for Firms. Marketing Science, Vol. 12, No. 2, spring 1993, pp. 125- 142

[19] Cann, C. W.: An Examination of business-to-business Customer Satisfaction: The Depth of Use/Integration of High Technology Products, Industrial Marketing, Ph. D., State University of New York at Binghamton, 1984, pp. 234

[20] Parasuraman, A., Zeithalm, V. A., Berry, L. L.: A conceptual model of service quality and its implications for future research », Journal of marketing, No. 49, 1985, pp. 42

[21] Getty, J. M., Getty, R. L.: Lodging Quality Index (LQI): Assessing hotel guests' perceptions of quality delivery, International Journal of Con temporary Hospitality Management, Vol. 15, No. 2, 2003, pp. 94-104

[22] Jain, S. K., Gupta, G.: Measuring service quality: SERVQUAL vs. SERVPERF Scales, VIKALPA, Vol. 29, No. 2, 2004, pp. 25-37

[23] Ambrož, M., Praprotnik, M.: Organisational effectiveness and customer satisfaction, Organizacija (Kranj), Vol. 41, No. 5, Sept. /Oct. 2008, pp. 161-173

[24] Edvardsson, B.: Making service quality improvement work. Managing Service Quality, Vol. 6, No. 1, 1996, pp. 49-52
[25] Yuksel, A.: Managing customer satisfaction and retention: A case of tourist destinations, Turkey Journal of Vacation Marketing, Vol. 7, No. 2, 2001, pp. 153-168

[26] Lewis, R. C.: The measurement of gaps in the quality of hotel services, International Journal of Hospitality Management, Vol. 6, No. 2, 1987, pp. 83-88

[27] Mey, L. P., Akbar, A. K., Fie, D. J. G.: Measuring service quality and customer satisfaction of the hotels in Malaysia: Malaysian, Asian and non-Asian hotel guests, Journal of Hospitality and Tourism Management, Vol. 13, No. 2, 2006, pp. 144-160

[28] Hansemark, O., Albinsson M.: Customer satisfaction and retention: the experiences of individual employees, Managing Service Quality, Vol. 14 No. 1, 2004, pp. 40-57.

[29] Bellou, V.: Achieving long-term customer satisfaction through organizational culture: Evidence from the health care sector, Managing Service Quality, Vol. 17, No. 5, 2007, pp. $510-522$

[30] Anderson, E. W., Sullivan, M. W.: (1993): The Antecedents and Consequences of Customer Satisfaction for Firms. Marketing Science, Vol. 12, No. 2, spring 1993, pp. $125-142$

[31] Fornell Claes, C.: A National Customer Satisfaction Barometer: The Swedish Experience, Journal of Marketing. Vol. 56, 1992, pp. 6-21

[32] Brady, M. K., Cronin, J. J. Jr.: Some new thoughts on conceptualizing perceived service quality: A hierarchical approach, Journal of Marketing, Vol. 65, No. 3, 2001, pp. 34-49

[33] Caruana, Money, A. H., Berthon, P. R.: Service Quality and Satisfaction - the moderating role of value, European journal of marketing, Vol. 34, No. 11/12, 2000, pp. $1338-1353$

[34] Doolin, B., Dillon, S., Thompson, R., Corner, J. L.: Perceived risk, the Internet shopping experience and online purchasing behavior: A New Zealand perspective, Journal of Global Information Management, 13 (2), 2005, pp. 66-88

[35] Wu, W. Y., Chang, M. L.: The role of risk attitude on online shopping: Experience, customer satisfaction, and repurchase intention, Social Behavior and Personality, Vol. 35, No. 4, 2007, pp. 453-468.

[36] Soderlund, M., Ohman, N.: Behavioral intentions in satisfaction research revisited, Journal of Consumer Satisfaction, Dissatisfaction and Complaining Behavior, Vol. 16, 2003, pp. 53-66 